Sergey Kullanda

Institute of Oriental Studies of the Russian Academy of Sciences (Moscow); kullanda@java.msk.ru

\title{
Accentuation in early Malay and Javanese epigraphy
}

\begin{abstract}
The paper deals with long vowels in early Old Malay and Old Javanese epigraphy. It is argued that long vowels in inherent wordstock marked stress in Old Malay, hence the shift of the length, resp. stress, if a suffix or enclitic is added to a stressed word. Words lacking the marker of vowel length were phonologically unstressed like Japanese atonal zenhei forms. In early Old Javanese the length was etymological and diacritics showing vowel length could not be used, as in early Old Malay, as stress marks on etymologically short syllables. However, if, due to word formation processes, two long vowels emerged in a word, only the second retained length mark; stress shift akin to that of Old Malay was probably taking place. It appears that both early Old Javanese and early Old Malay were characterized by tonal system of accentuation with sliding tonal platforms.
\end{abstract}

Keywords: accentuation, tonal systems, epigraphy, Malay, Javanese.

Modern Malay/Indonesian and Javanese know neither dynamic stress or tone nor the differentiation of vowels by quantity/duration (short/long). Early Old Malay and Old Javanese inscriptions, however, regularly marked the length of vowels not only in Sanskrit loanwords where it was phonemically and semantically significant, but also in inherited wordstock where it was quite probably superfluous, at least with regard to Old Malay, or sometimes etymologically unfounded. Hence the need to explain these cases as well as the lack of length marking in a large number of vernacular words. As to stress marking in Old Malay, scholars have long been aware that "[i]n the inscriptions, the quality of the vowel varies with the presence or absence of an accent. This fact, which had already been pointed out by Kern (1913; VG, VII: 212-213), is defined as follows by Blagden (1913a: 70): the addition of a suffix, or even simply an enclitic, to the root word, induces a shift in the accent of intensity; it is an old Indonesian law that has become somewhat obliterated in the Malay spoken today in the Peninsula, but classic Malay spelling shows that it was already used at an early date; thus we find marjahâti derived from jāhat, datūa derived from dātu, etc." (Sriwijaya 1992: 64-65). This explanation, however, does not take into account the existence of unstressed vernacular words and therefore fails to describe the system of Old Malay accentuation in toto, which is one of the purposes of my paper.

The relevant data are collected from early Old Malay (up to the late $9^{\text {th }}$ century A.D.) and early Old Javanese (up to the early $10^{\text {th }}$ century A.D.) epigraphy, since later texts do not mark vowel length in their Austronesian vocabulary. Early Malay inscriptions originate mainly from South Sumatra and Java. An Old Malay inscription dated to 822 of the Śaka era, i.e. A.D. 900, was encountered in the Philippines, on the Luzon Island. The reading of the relevant passages was verified, whenever possible, from photographs of inscriptions.

Since the principles of unorthodox marking of vowel length in Old Malay and Old Javanese differ, below they will be dealt with separately.

As mentioned above, in Old Malay, when suffixes or enclitics are added to disyllabic words with a long (at least in writing) first syllable, length marking on the latter is transferred to the next syllable. 
Cf. the following examples: dìri 'self' (Telaga Batu: 14) - dirĩña 'themselves' (Ibid. 15); jāhat 'evil; wicked' (Kota Kapur: 6) - marjjahāti 'to injure, harm' (Ibid.: 7); tāhu 'to know; knowledge' (Telaga Batu: 12) - tahū̃̃a 'their knowledge' (Ibid.: 11); dātu 'chief' (Telaga Batu: 10; Kota Kapur: 4) - datūa 'to become a chief' (Telaga Batu: 15; Kota Kapur: 4); waropāyā̃a 'their best means or expedient' (Talang Tuwo: 4; cf. Sanskrit varopāya-); kasīhan 'philtre' (Karang Brahi: 12-13; Kota Kapur: 6; if the diacritic were indeed marking length, it should have been marked on the first, etymologically long, syllable where the addition of the prefix $k a$ - resulted in the fusion of two vowels: ka-asih-an, cf. Old Javanese asih, kāsihan 'love' '), cf. Tag. pag-kasi 'love,' etc.

Thus, it appears that the length-marker in inherited wordstock was restricted to a single syllable of a word. ${ }^{2}$ In Sanskrit loanwords, length continued to be marked after the addition of enclitics, but with the penultimate syllable acquiring an additional 'length' as well. This seems to imply that the alleged 'length' actually marked stress/tone/pitch. It seems likely that the latter was usually expressed on the ultimate and penultimate syllables, but not on the antepenultimate ones (cf., however, supra, note 2.) $)^{3}$ An additional argument in favour of the aboveproposed interpretation of the Old Malay 'vowel-length' is the fact that it appears in etymologically short syllables; cf., for instance, hāji 'king' (the reflex of the same etymon in early Old Javanese where etymological length is regularly marked shows not a single example of the long penultimate syllable.) Moreover, when this Old Malay word was borrowed into Tagalog, it acquired paroxytonal stress in the process: Tag. harì, i.e. hàri?. ${ }^{4}$

It is worth noting that Philippine (and Formosan) reflexes of protolanguage etyma often, though not always, show stress or length on the syllable that is marked as long in Old Malay: Old Malay hanāu 'sugar palm' (Talang Tuwo: 2) - Bikol anáhaw, Tagalog anàhaw 'fan palm,' etc. (ACD s.v. * qanahaw; the only reflex with oxytonal stress is Hanunoo Zanaháw 'palm species'), Old Malay dīri 'self' (Telaga Batu: 14) - Tag. sa-rìli 'id.,' Old Malay kāyu 'tree, wood' (Talang Tuwo: 3) - Bikol káhoy 'tree, wood, timber,' Bontok kálew, Tag. kàhoy, Ilokano káyo 'id.', Kankanaey káiw 'wood, timber, tree, shrub,' etc. (ACD s.v. *kaSiw, $)^{5}$ Old Malay tūwa 'poison' (Karang Brahi: 12; Kota Kapur: 5) - Tag. tùba, Ilokano tùba 'id.,' etc. (ACD s.v. *tuba; all the reflexes are stressed on the penultimate syllable), Old Malay marsārak 'to separate oneself from' (Talang Tuwo: 10) - Tag. sàlak 'id.,' Old Malay lāki 'man; male'

${ }^{1}$ As to the meaning of the Old Malay word, cf. Latin venēnum 'potent herb; poison' deriving from venus 'love; charm' (Ernout, Meillet 2001: 719, 721-722; De Vaan 2008: 660).

${ }^{2}$ A single exception to this rule, as well as to that of the antepenultimate syllable being unstressed, is Old Malay larīyākan (Telaga Batu 9-10) 'make or help someone to flee:' cf. mam-lāri (Ibid.: 9) 'to flee.' Unfortunately, in Casparis's publication the former word is cited in three different forms, i.e. larīyākan (Casparis 1956: 33), -lariyākan (Ibid.: 40, note 31) and lariyakan (Ibid.: 347), and no photograph of the inscription is available to verify the transcription.

${ }^{3}$ This is also implied by the fact that in Modern Malay the original vowel * $a$ (represented in cognate languages such as, for instance, Tagalog and Javanese) changed into schwa in the antepenultimate syllable of trisyllabic forms (cf. the prefixes ${ }^{*} m a(N)-,{ }^{*} p a(N)$ - changing into ${ }^{*} m \partial(N)-,{ }^{*} p \partial(N)-$, where $N$ is any nasal), yet survived in disyllabic words: makan 'to eat' (cf. ikan 'fish, lit. food,' a derivate of the same root with the article $i$-), mabuk 'drunk' (< *buk 'drugged'; for more details, see Kullanda 2010), etc. The spelling kadātuan (Telaga Batu 8, 11) could be due to the change of $-u$ - into $-w$ - before a vowel. Cf. also infra, note 9.

${ }^{4}$ Malay $j$ regularly changes into Tagalog $r$ in early borrowings; cf. Malay taraju 'scales; balance' (from Persian tarāzu 'id.') > Tag. talarò (talàro?) 'id.,' etc.

${ }^{5}$ Penultimate stress is more prevalent among the relevant cognates, though there are such exceptions as Pangasinan kiéw 'tree, stick, timber,' Agta kayú 'living tree,' Casiguran Dumagat kayó 'tree, wood, stick,' Palawan Batak kayó 'wood, tree, stick.' 
(Talang Tuwo: 13) - Tag. la-làki 'id,' Isneg láki 'male,' Bontok láki 'male animal,' Batad Ifugao lāki 'a male pig' (ACD s.v. *laki,) Old Malay lāgi 'still; more; moreover' (Talang Tuwo 9) Tag. làgi? 'always'. 6

At the same time, words without any markers of vowel length, resp. stress, including cases with added enclitics and suffixes, can be encountered in the same inscriptions: wañakna 'in quantity; numbering' (Kedukan Bukit: 7), wañakta 'you all' (Karang Brahi: 6; Kota Kapur: 2), winiña 'their wives' (Talang Tuwo: 8), dalaiñ̃a 'the inside of' (Karang Brahi: 7; Kota Kapur: 3), mamhidupi 'to bring up, raise' (Talang Tuwo: 6), etc. It seems likely that those were phonologically unstressed words, akin to Japanese atonal zenhei forms. Interestingly, in Tagalog and some other Philippine languages where stress is phonologically relevant, the reflexes of etyma whose derivates in Old Malay show no length markers have oxytonal stress which can be regarded, like in Japanese, as a demarcation accent at the end of the phonetic word (cf. Dybo 2005: 103-111): Old Malay niminumina 'drunk by them' (Talang Tuwo: 5) - Tag. uminóm 'to drink,' inumín 'a drink,' Isneg inúm, Bontok Rinúm, Bikol inôm, Cebuano inúm, Hanunoo Zinúm, etc. 'to drink' (ACD s.v. *inum), Old Malay mata 'eye' - Tag. matá, Bontok matá, Bikol matá, Ilokano matá 'id.', mata-mata-án 'to stare at,' etc. (ACD s.v. $\left.{ }^{*} m a C a\right),{ }^{7}$ Old Malay huma 'dry rice field' - Bikol umá 'lowland rice field, farm, field', Cebuano umá 'piece of land on which crops or animals are raised, cultivate or till a piece of land', Ifugaw umá 'a tract of land cleared for cultivation', Ilokano umá 'clearing, tract of land cleared for cultivation', Isneg umá 'clear a patch of ground preparing it for a ricefield', etc. (the only exception is Bontok zuma 'cut down grass, make a swidden'), Old Malay ñiyur 'coconut' - Bikol niyóg, Palawan Batak niyóg, Ifugaw niyúg, Ilokano nióg, Pangasinan nióg, Tag. niyóg 'id.', etc. (ACD s.v. *niuR.) ${ }^{8}$ This is indirect evidence in favour of the above-mentioned treatment of Old Malay 'long vowels'. Yet another argument in favour of the hypothesis that Old Malay words without marked long vowels were phonologically unstressed are Old Malay mantrā 'magical formula' and wadū 'servant; follower', being adaptations of Sanskrit mantra and badva (both with a short final syllable) respectively. Oxytonal stress in Old Malay is implied by Modern Malay mentera with schwa in antepenultimate and penultimate positions. It seems likely that loanwords without

${ }^{6}$ The divergence between Old Malay 'length' and Tagalog stress can be seen, e.g., in the reflexes of protolanguage etyma with shwa. The latter changed to $i$ in Tagalog and often attracted stress, especially in the final syllable, while in Old Malay it changed to $a$ and, as far as we can judge, remained unstressed: cf. such pairs as Old Malay dātam 'to come' (Telaga Batu: 18; Kedukan Bukit: 7, 9) - Tag. datíng 'id.' (cf. Old Javanese dataך 'id.' borrowed from Proto-Malay (?), since in an inherited word * $d$ - would have changed to $r$-), Old Malay -tānam 'to plant' (Talang Tuwo: 2) - Tag. taním 'plant' (cf. Old Javanese tanam 'to plant'), Old Malay mar-lapas 'to free oneself from, to leave' (Kedukan Bukit 4) (Modern Malay lepas) - Tag. naka-lipas 'past, bygone.' The only exception is Old Malay dalam(ña) 'the inside of' - Tag. làlim 'depth.' Divergences also occur in the reflexes of etyma with * $u$ in an open final syllable: cf. Old Malay āku 'I' (Telaga Batu: passim; Karang Brahi: 9, 14; Kota Kapur: 4, 7, 8) - Bikol akó, Hiligaynon akú, Tag. akó, etc. 'id.', Old Malay wātu 'stone' (Kota Kapur: 7) - Tag. bató 'id;' Philippine reflexes invariably have oxytonal stress yet cf. Kanakanabu váatu 'stone' (ACD s.v. *batu $)$

7 The only exceptions are Kankanaey máta, Palawan Batak máta 'eye.'

8 True, there are numerous exceptions to this rule that so far defy explanation, e.g. Old Malay waram 'thing,

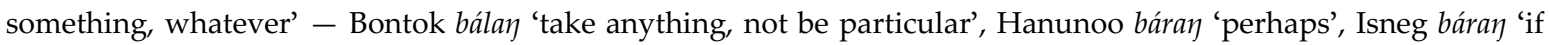
perhaps, haply, let us hope', Kankanaey bálay 'provided, it is to be seen if'. Occasionally reflexes of relevant protolanguage etyma are controversial with regard to stress: Old Malay sumpah, parsumpahan 'oath' - Bikol sumpá? 'oath', Tag. sumpâ id., parsumpaín 'to swear in, administer the oath', Pangasinan sumpá 'amulet, antidote, oppose, resist', yet Hiligaynon súmpa? 'oath, sworn statement, vow', Casiguran Dumagat súmpa 'oath, pledge, act of swearing', etc., Old Malay wulan 'moon; month' - Kanakanabu vuáne, Tag. buwán (intervocalic $l$ was regularly dropped in Tagalog inherited wordstock), Casiguran Dumagat bulán, Pangasinan bulán, yet Bontok búlan, Ilokano búlan, Isneg búlan id. 
long syllables that were not regarded, like inherited words, as phonologically atonal, could acquire a regular oxytonal stress instead of a demarcational one. ${ }^{9}$

This system is strikingly similar to that of Tagalog. The latter also shows "the 'sliding' character of accent contour: oxytones transmit their accent to the following syllable of suffix, thus restoring oxytonese in derivates. Similarly paroxytones, while suffixed, transmit their accent to the next syllable restoring paroxytonese in derivates... This 'sliding' type of accent contours sends us in search of analogies to this paradigmatic accent system among tonal languages with 'sliding' tonal platforms" (Dybo 2005: 174; the translation is mine.)

Thus, it seems likely that the language group ancestral to (Old) Malay and Tagalog was characterized by a tonal system of accentuation with sliding tonal platforms.

The accentuation in early Old Javanese was somewhat different. The length there was invariably etymological, arising after the loss of a consonant owing to either a compensarory lengthening or a fusion of identical vowels. It was clearly regarded as such by early Old Javanese speakers, and, therefore, diacritics indicating vowel length could not be used as stress marks on short syllables. ${ }^{10}$

However, if, due to word formation processes, two long vowels emerged in a word, only the second retained length mark: rāma 'village elder' (Kurungan 1a: 4) - karamān 'village counsil' (Ibid. 1a: 1); nāyaka 'title of an official' (a Sanskrit loanword) (Mantyasih I, 2a: 9) kanayakān 'corporation of nāyaka's' (Ibid. 1b: 3); banyāga 'merchant' (a Prakrit loanword, cf. Sanskrit vanijaka-) (passim in inscriptions) - kabanyagān 'guild of merchants' (Tulang Air I, a: 34). As it appears from the above-cited examples, this rule was applied not only to inherited wordstock, but also to assimilated borrowings. It can be surmised that vowel length acquired stress/tonal characteristics as well, as it is the case in Russian where the stressed vowel is longer than the unstressed; hence the formation of a 'sliding' accent contour in Old Javanese

${ }^{9}$ At first glance it would seem that the Old Malay alternation kadātuan/kadatuan 'state, principality; princely residence' (the reality of spelling without length marking was verified from the photograph of the Kota Kapur inscription where one can see the forms dātu and datūa as well) defies interpretation. It can be surmised, however, that here we have to do with an attempt to distinguish artificially, at least in writing, different shades of meaning: for instance, kadatuan in the word combination kadatuan śrīwijaya clearly means 'the kingdom of Śrīwijaya' while kadātuan in the Telaga Batu inscription may well signify 'residence, palace'. Such alternation of long and short vowels was practiced, e.g., in Old Javanese in order to avoid undesirable homonymy. Thus, the word răma meaning 'father' was written with a short vowel in the first syllable and the same word meaning 'village elder' - with a long one, though etymologically the relevant vowel was long in both cases. It goes back to the fusion of vowels of the honorific prefix ra- and the word ama 'father' (cf. Paiwan ama, Tagalog amá, etc. 'id.'). A similar expedient was used in Russian before the reform of orthography in 1918: the divergent reflexes of a formerly single word were written as $\mathcal{M и р}$ in the meaning 'peace' yet as мipr (in violation of the orthography, since $i$ could not be used in preconsonantal position) in the meaning 'world; universe'.

10 True, many lingusts believe that "characters and diacritics denoting long vowels had been borrowed in the course of adoption of Indian script for the transcription of Sanskrit words, while in the inherent lexemes vowel length was marked arbitrarily... For example, A.K. Ogloblin holds, after L.-Ch. Damais, that long vowels in the original Javanese words “...had the only function of fulfilling metre requirements in quantitative verses of Indian origin;... the opposition of long and short vowel was not functional, except in learned poetry... only an enormous number of borrowings serve as a support for the quantitative opposition..." (Ogloblin 1996: 50). At the same time, Ogloblin agrees that a compensatory lenthening of a vowel after the loss of ${ }^{*} R$ could have taken place occasionally, as in $u \bar{l}$ [snake. - S.K.] from *ulaR (Ibid.)... Yet such an explanation would imply that the scribes in the ninthcentury Java were versed in historical linguistics: otherwise, given the alleged irrelevance of vowel length in Old Javanese, they could hardly have correctly identified the etymological length of a vowel. The only alternative to such a far-fetched assumption is the hypothesis that at least at the time of the borrowing of writing the relevant phonemes were long and differed in quantity from the short ones" (Shmelev 2002: 76-77). 
that resembles, though by no means is identical to that of Old Malay and Tagalog. It is not inconceivable (though, of course, indemonstrable) that words containing only short vowels were phonologically unstressed, like the above-mentioned Japanese zenhei forms, and their accentuation eventually spread to once-stressed words, which led - as it did, mutatis mutandis, in Malay - to the formation of the modern Javanese system.

It may be inferred that Old Malay and Old Javanese literati elaborated original conceptions of stress/tone in their native languages, not going back to Sanskrit grammar, as well as means for stress marking.

\section{References}

ACD - The Austronesian Comparative Dictionary, web edition. By Robert Blust and Stephen Trussel. Available: www.trussel2.com/ACD (ongoing: 2010-), revision 7/2/2015

Blagden 1913[a] - C.O. Blagden. The Kota Kapur (Western Bangka) Inscription. Journal of the Straits Branch of the Royal Asiatic Society, 64: 69-71.

Casparis 1956 - J.G. de Casparis. Selected Inscriptions from the 7th to the 9th Century A.D. II. Bandung: Masa Baru.

Coedès 1930 - Georges Coedès. Les inscriptions malaises de Çrīijiaya. Bulletin de l'Ecole française d'Extrême-Orient, 30: 29-80.

Dybo 2005 - V.A. Dybo. Raboty E.D. Polivanova po japonskim aktsentnym sistemam i obschaja aktsentologija. In: Aktual'nye voprosy japonskogo i obschego jazykoznanija. Pamjati I.F. Vardulja. Moscow: 101-176.

Ernout, Meillet 2001 - Alfred Ernout, Antoine Meillet. Dictionnaire étymologique de la langue latine. Histoire des mots. Retirage de la 4e édition augmentée d'additions et de corrections par Jacques André. Paris.

Kern 1913 - H. Kern. Inscriptie van Kota Kapur (eiland Bangka; 608 Çāka). Bijdragen tot de Taal-, Land- en Volkenkunde van de Koninklijk Instituut 67: 393-400 (reprinted in: H. Kern. Verspreide Geschriften VII: 205-214).

Kullanda 2010 - Sergey Kullanda. The etymology of Malay amuk. Studia Anthropologica: Sbornik statej v chest' M.A. Chlenova. Pod red. A.M. Fedorchuka i S.F. Chlenovoj. Moscow/Jerusalem.

Ogloblin 1996 - A.K. Ogloblin. Ocherk diakhronicheskoj tipologii malajsko-javanskikh jazykov. Moscow.

Shmelev 2002 - Aleksei A. Shmelev. Long vowels in Old Javanese: were they phonemic? Malay-Indonesian Studies XV. Moscow: Nusantara Society and The Asia and Pacific Museum: 76-81.

Sriwijaya 1992 - Sriwijaya: History, Religion and Language of an Early Malay Polity. Collected Studies by George Coedès and Louis-Charles Damais. Monograph of the Malaysian Branch of the Royal Asiatic Society no. 20. Kuala Lumpur.

De Vaan 2008 - Michiel de Vaan. Etymological Dictionary of Latin and the other Italic Languages. Leiden/Boston.

С. В. Кулланда. Акцентуация в ранней древнемалайской и древнеяванской эпиграфике.

В статье рассматривается обозначение долгих гласных в ранней древнемалайской и древнеяванской эпиграфике. Автор считает, что в письменном древнемалайском долгие гласные в исконных словах обозначали ударные слоги, отсюда переход долготы, resp. ударения, на последующий слог при добавлении суффикса или энклитики. Слова без обозначения долготы были, видимо, фонологически безударными, подобно японским дзенхейным формам. В раннем древнеяванском долгота была обусловлена этимологически, поэтому ею не могли обозначаться, как в малайском, этимологически краткие слоги. Однако если в процессе словообразования в слове появлялись два долгих гласных, первый из них терял на письме долготу, т.е. происходил, как и в древнемалайском, переход ударения. Видимо, в обоих языках существовала акцентуационная система со скользящими тональными платформами.

Ключевые слова: акцентуация, тональные системы, эпиграфика, малайский, яванский. 
